\title{
MEMAHAMI DAN MEMAKNAI BERBAGAI PERATURAN, KETETAPAN, DAN HUKUM DALAM TAURAT
}

\author{
Elisamark Sitopu \\ Institut Agama Kristen Negeri Tarutung
}

\begin{abstract}
This paper discusses various kinds of provisions, regulations and laws in the Torah. Generally, the perspective about the Torah is often too narrow and simple, even though the understanding of the Torah is actually broad. Our view of the Torah often refers only to the laws, rules and regulations of the Old Testament. This view is produced by understanding the New Testament which results in the Torah being seen as a part that produces rigid laws that often have negative tendencies. To overcome this problem, the aim of this article is to provide a more comprehensive explanation about the various rules and regulations in the Torah.
\end{abstract}

Keywords: Torah, instruction, teaching, law

\begin{abstract}
ABSTRAK
Artikel ini membahas berbagai macam ketetapan, peraturan dan hukum dalam Taurat. Secara umum, pandangan tentang Taurat seringkali terlalu sempit dan sederhana, seringkali hanya merujuk pada hal-hal yang berkaitan dengan hukum-hukum, peraturan-peraturan atau regulasiregulasi. Pandangan yang demikian menghasilkan pandangan yang bertendensi negatif dan keliru akan Taurat. Taurat dipahami sebagai suatu kitab yang dipenuhi kekakuan, padahal mestinya tidak demikian. Untuk mengatasi masalah ini, tujuan artikel ini adalah untuk menyediakan penjelasan yang lebih komprehensif tentang berbagai peraturan dan ketetapan dalam Taurat.
\end{abstract}

Kata Kunci: Torah, pengajaran, hukum

\section{PENDAHULUAN}

Berbagai ketetapan, aturan, dan hukum adalah pokok-pokok yang dapat kita lihat ketika kita membaca kitab Taurat. Banyak hal yang diaturkan dalam kehidupan orang Israel dalam kehidupan kesehariannya, baik itu dalam hal jasmani maupun kerohaniaannya. Ada aturan tentang peribadatan, aturan terkait dengan makanan, aturan tentang bermasyarakat, dan sebagainya. Semua aturan itu membuat hidup orang Israel dipenuhi oleh berbagai aturan. Ada hal-hal yang boleh mereka lakukan dan ada juga hal-hal yang tidak boleh mereka lakukan. Orang Kristen saat ini seringkali juga memahami bahwa kitab Taurat adalah kitab aturan, yang terkesan kaku dan using. Namun apakah pendapat atau pemahaman ini benar?

32 Korespondensi mengenai artikel dapat dilakukan kepada: Elisamark Sitopu, Institut Agama Kristen Negeri Tarutung,

Jl. Raya Tarutung-Siborong KM 11, Silangkitang, Sipoholon, Tapanuli Utara (22452), Indonesia

E-mail Corresponding: elisamarksitopu1977@ gmail.com 
Artikel ini membahas berbagai macam ketentuan, peraturan dan hukum dalam Taurat. Pandangan umum tentang Taurat seringkali terlalu sempit dan sederhana. Pandangan tentang Taurat dalam Perjanjian Lama (istilah Perjanjian Lama selanjutnya disingkat PL) seringkali hanya merujuk pada hal-hal yang berkaitan dengan hukum-hukum, peraturan-peraturan atau regulasi-regulasi. Pandangan yang demikian nampaknya berasal dari pengaruh pemahaman kita akan Perjanjian Baru (istilah Perjanjian Baru selanjutnya disingkat PB) yang dianggap lebih baik daripada Perjanjian Lama. Hasilnya, pandangan-pandangan kita menjadi sempit dan dangkal. Kita umumnya memandang hukum-hukum tersebut sebagai sesuatu yang kaku, using dan bahkan tidak jarang bertendesi negatif.

Untuk memperbaiki pandangan atau pemahamaan di atas, tulisan ini bertujuan untuk menyediakan penjelasan yang lebih mendalam dan komprehensif, yakni dengan sistemasika pembahasan sebagai berikut. Berkaitan hal tersebut, pertama, tulisan ini bermaksud menjernihkan pemahaman tentang istilah dan pengertian Taurat. Setelah itu, penulis akan menjelaskan beberapa aturan atau hukum yang terdapat dalam Taurat dan memberikan pemahaman dan pemaknaan terhadapnya.

\section{PEMBAHASAN}

\section{Tora dalam Perspektif Ibrani \\ Istilah Torah}

Pandangan yang seringkali terjadi, baik itu dari literatur Yahudi dan Kristen mengenai pengertian tora merujuk atau mengacu kepada hukum. Hal ini dapat dideteksi dari bahan non pentateukh, seperti PB. Dalam PB, pentateukh sering disebut dengan istilah hukum the law (Matius 5:17-18), hukum Musa the law of Moses (Lukas 2:22) atau merujuk secara sederhana pada Musa Moses (Lukas 16:31;Kisah Para Rasul 15:21). Penulis-penulis PB juga menggunakan istilah hukum untuk PL secara keseluruhan. Hal ini terdapat dalam Yohanes 10:34 dengan memperhatikan apa yang terdapat dalam Mazmur 82:6. Juga dalam I Korintus 14:21dengan memperhatikan Yesaya 28:11-12. Di samping itu, walaupun PL memiliki pengekspresian yang berbeda terhadap istilah ini, misalnya frasa-frasa kitab dari hukum Allah, kitab dari hukum Musa atau juga secara sederhana dengan istilah kitab hukum, namun acuan pengertiannya tetap saja mengarah kepada hukum. Dapat dikatakan bahwa penggunaan ini secara berangsur-angsur ingin memberikan judul kepada Pentateukh itu sendiri. (Desmont T. Alexander 2003:497).

Hukum dalam PL adalah terjemahan yang biasa digunakan dari kata Ibrani tora, namun penyamaan ini tidak selalu tepat. Konsep dalam bahasa Inggris untuk tora yakni law atau hukum, maknanya lebih sempit dari apa yang seharusnya 
terpancar dari istilah tora dalam bahasa Ibrani. Itu artinya, istilah tora tidak dapat didefenisikan dengan satu pengertian saja dan hal ini perlu dipahami sebelum membahasnya lebih jauh (Desmont T. Alexander 2003:497).

Dalam bahasa Ibrani, hukum dijelaskan dengan berbagai macam istilah ataupun kata. Hukum bisa diartikan tsiwwa atau perintah, bisa juga eda atau peringatan, huq atau undang-undang, bisa juga mishpat atau peraturan (Andrew E. Hill, John H. Walton 1996 :114). Sejalan dengan kenyataan ini, Ch. Barth mengutarakan bahwa pembaca Alkitab seringkali dipusingkan dengan berbagai macam istilah yang sering digunakan untuk hukum-hukum Allah, ia menyebutkan paling sedikit ada delapan sebutan. Itu artinya, Ch. Barth menyebutkan lebih banyak istilah atau kata dari apa yang telah disebutkan sebelumnya. Pertama, undang-undang tora. Kedua, ketetapan huq. Ketiga, hukum mishpat. Keempat, perintah mitswa. Kelima, peraturan eda. Keenam, firman dabar. Ketujuh, sabda imra. Kedelapan, titah pikkudim (Ch. Barth 1970:238)

Kenyataan akan perbedaan-perbedaan ini telah memunculkan pertanyaan akan persamaan dan perbedaan. Menurut Ch. Barth, beberapa diantaranya mempunyai artinya sendiri-sendiri, misalnya yang satu berkenaan dengan suatu perintah atau suruhan sementara yang lain berkaitan dengan suatu larangan. Atau yang satu berkaitan dengan ketetapan yang berlaku secara mutlak sementara yang satu lagi berkenaan dengan suatu ketetapan yang bersyarat. Namun demikian Ch. Barth menekankan kesatuan dari keseluruhan hukum-hukum itu. Walaupun berbeda dalam hal bentuk, isi, jiwa, lapangan hukum, tempat dan jaman asalnya, semunya dinyatakan dalam pembentukan perjanjian Allah di gunung Sinai, dengan perantaraan Musa, dan berwibawa karena merupakan perintah Tuhan yang menyatakan kasih dan berkat Allah. Di samping itu, semuanya juga bertujuan untuk menciptakan, memelihara, serta memperbaharui umatNya sendiri, yakni Israel (Ch. Barth 1970:238).

\section{Pengertian Tora}

Tora merupakan bagian dari Alkitab yang terdiri dari lima kitab pertama, mulai dari Kejadian sampai dengan Ulangan. Nama tora sendiri berasal dari kata Ibrani tora yang berarti perintah instruction (David Noel Freedman 1992:605). Kata benda tora dihubungkan dengan kata kerja hora yang berarti mengajar to teach yang merupakan bentuk hiphil dari yara. Hubungan ini memberi pengertian bahwa tora diterjemahkan dengan pengajaran atau perintah teaching, instruction. Suatu survei dari dua ratus dua puluh kata tora dalam PL, menggambarkan adanya tiga aspek penting berkaitan dengan kata ini. Yang pertama, pengajaran atau perintah untuk dipelajari. Yang kedua, perintah untuk dipatuhi. Yang ketiga, petunjuk, arahan atau bimbingan untuk hidup dalam situasi tertentu (Desmont $\mathrm{T}$. Alexander 2003 : 499).

Kata ini sendiri dikenal sebagai pentateukh dari kata Yunani pentateochos yang berarti lima buku a five book-work. Juga dikenal sebagai lima buku Musa 
five books of Moses. Yang didalamnya tersusun dalam bentuk prosa, puisi dan hukum dalam suatu narasi kronologis yang berasal dari ribuan tahun (David Noel Freedman tanpa tahun 1992:605)

\section{Penggunaan Tora dalam Pentateukh}

Kata tora, terdapat lima puluh enam kali dalam pentateukh dan digunakan dengan lima cara yang berbeda (Desmont T. Alexander 2003:497). Yang pertama, merujuk kepada pernyataan pribadi atau individu. Bagian ini termasuk bagian yang jarang ditemukan namun ada beberapa, misalnya dalam Bilangan 19:14 'Kemudian imam Eleazar harus mengambil dengan jarinya sedikit dari darah lembu itu, lalu haruslah ia memercikkan sedikit ke arah sebelah depan Kemah Pertemuan sampai tujuh kali'. Keluaran 12:49 'Satu hukum saja akan berlaku untuk orang asli dan untuk orang asing yang menetap di tengah-tengah kamu.' Bilangan 31:21 'Lalu berkatalah imam Eleazar kepada para prajurit, yang telah pergi bertempur itu: "Inilah ketetapan hukum yang diperintahkan TUHAN kepada Musa.'

Yang kedua, sekelompok hukum atas suatu subjek tunggal. Hal ini secara aktual merupakan hal paling lazim terdapat dalam pentateukh. Hal ini secara khusus berkali-kali dalam topik-topik ataupun ikhtisar-ikhtisar dalam kitab Imamat dan Bilangan. Sebagai contoh hukum nazir dalam Bilangan 6:13 'Dan inilah hukum tentang seorang nazir. Apabila waktu kenazirannya genap, ia harus dibawa ke pintu Kemah Pertemuan, ayat 21 'Itulah hukum tentang orang nazir yang menazarkan persembahannya kepada TUHAN berdasarkan kenazirannya, belum dihitung apa yang ia mampu mempersembahkan di samping itu. Sesuai dengan bunyi nazar yang diikrarkannya, demikianlah harus dilakukannya berdasarkan hukum tentang kenazirannya. Atau hukum korban bakaran dalam Imamat 6:9 'Perintahkanlah kepada Harun dan anak-anaknya: Inilah hukum tentang korban bakaran. Korban bakaran itu haruslah tinggal di atas perapian di atas mezbah semalam-malaman sampai pagi, dan api mezbah haruslah dipelihara menyala di atasnya.'

Yang ketiga, suatu kumpulan khusus mengenai hukum. Bagian ini hanya terdapat dua kali, yakni dalam penekanan sepuluh perintah dalam Keluaran 24:12 'TUHAN berfirman kepada Musa: "Naiklah menghadap Aku, ke atas gunung, dan tinggallah di sana, maka Aku akan memberikan kepadamu loh batu, yakni hukum dan perintah, yang telah Kutuliskan untuk diajarkan kepada mereka.' Juga hukum deutronomi dalam Ulangan 31:9 'Setelah hukum taurat itu dituliskan Musa, maka diberikannyalah kepada imam-imam bani Lewi, yang mengangkut tabut perjanjian TUHAN, dan kepada segala tua-tua Israel.'

Yang keempat, suatu gambaran umum untuk hukum Allah. Secara umum hal ini selalu terdapat dalam bentuk plural dari tora yaitu torot. Hal ini meliputi penyebutan tunggal tora dalam Kejadian, yakni Kejadian 26:5 'karena Abraham

35 | Memahami dan Memaknai berbagai Peraturan, Ketetapan, dan Hukum dalam Taurat..., Sitopu, Elisamark Jurnal Christian Humanioran | http://e-journal.iakntarutung.ac.id/index.php/humaniora 
telah mendengarkan firman-Ku dan memelihara kewajibannya kepada-Ku, yaitu segala perintah, ketetapan dan hukum-Ku.'Hal yang sama juga terdapat dalam bagian lain pentateukh, misalnya dalam Keluaran 18:16 'Apabila ada perkara di antara mereka, maka mereka datang kepadaku dan aku mengadili antara yang seorang dan yang lain; lagipula aku memberitahukan kepada mereka ketetapanketetapan dan keputusan-keputusan Allah.' Ulangan 4:8 'Dan bangsa besar manakah yang mempunyai ketetapan dan peraturan demikian adil seperti seluruh hukum ini, yang kubentangkan kepadamu pada hari ini?' Tema utama bagianbagian ini adalah tekanan bahwa Tora berasal dari Yahweh yang menggambarkan bahwa Tuhan telah berbicara dengan otoritasnya sendiri dan merujuk pada perintah dan syarat-syaratnya secara menyeluruh.

Kelima, suatu kombinasi dari narasi dan hukum. Hal ini terjadi pada bagian deutronomi. Di sini tora tidak dapat dibatasi hanya pada pengertian hukum saja. Muncul pertanyaan penting mengenai bentuk literer yang sebenarnya dari tora. Dengan demikian ia harus dilihat dari kerangka narasi seluruh pentateukh. Dengan demikian, kini sudah menjadi jelas bahwa ketika berbicara mengenai Tora dalam PL, rujukan kita tidak saja mengacu kepada satu pengertian saja namun bisa juga mengacu kepada beberapa hal sebagaimana yang telah disebutkan di atas. Ia harus dipahami secara lebih dinamis, agar kekayaan yang tersimpan didalamnya dapat digali dengan maksimal. Itu artinya, ketika istilah ini dijumpai lagi dalam pembahasan selanjutnya, bayangan kita sudah menjadi lebih jelas akan pengertian istilah ini.

\section{Memahami dan Memaknai Berbagai Macam Ketetapan, Peraturan, dan Hukum dalam Kitab Taurat}

Tidak dapat dipungkiri bahwa dalam banyak segi hukum atau perundangundangan yang terdapat dalam pentateukh, mempunyai kemiripan dengan sistem hukum yang ada dan berlaku di negara-negara tetangga Israel. Ini terjadi karena Israel terbentuk dan berada dalam suatu dunia yang berkembang. Dalam hal ini, meliputi 'timur dekat' seperti Mesopotamia dan Mesir (Herman Hendriks 1990:35). Hal ini akan dijelaskan lebih lanjut dalam makalah ini.

Dalam memahami dan memaknai berbagai macam ketetapan, peraturan dan hukum dalam Taurat, penulis akan mencoba menguraikan empat hukum yang terdapat dalam kitab taurat. Pertama, sepuluh perintah (Keluaran 20) yang dipahami berasal dari periode terdahulu. Kedua, kitab perjanjian (Keluaran 21-23) yang berasal dari periode para hakim. Ketiga, hukum deutronomi (Ulangan 12-26) yang berasal dari abad ketujuh pada masa pemerintahan Yosia. Keempat, hukum kekudusan (Imamat 17-26) yang berasal dari abad keenam.

\section{Sepuluh Perintah}

Secara umum, sepuluh perintah ini dipahami sebagai sesuatu yang berasal dari Musa. Wahono mengatakan bahwa sepuluh perintah atau dasa firman ini, 
terdiri dari dua versi. Yang pertama, versi menurut sumber elohist (Keluaran 20:217) sementara yang kedua, versi yang berasal dari sumber deutronomist (Ulangan 5:6-10). Dalam uraiannya, Wahono menegaskan bahwa kemungkinan besar, kedua versi ini berasal dari satu versi asli yang lebih tua dan pendek. Kemunculannya menjadi dua versi, lebih dikarenakan penjabaran dari versi kuno yang asli itu (Wismoady Wahono 2002:112)

Perbedaan yang terdapat dalam pada dua versi ini, terdapat dalam pandangan teologis mereka berkenaan dengan pemberlakuan hukum hari sabat. Versi elohist atau priest mengalaskan pemberlakuan hukum hari sabat itu pada cerita kejadian mula dalam Kejadian 1 sedangkan versi deutronomist mengalaskannya pada sakramen pembebasan dari perbudakan Mesir (Wismoady Wahono 2002:112). Dalam makalah ini, penulis lebih mengkonsentrasikan pembahasan pada versi yang pertama, yakni sebagaimana yang terdapat dalam Keluaran 20:2-17.

Dalam kitab Keluaran, dikisahakan bahwa setelah pembebasan dari laut Teberau, orang Israel melakukan perjalanan selama tiga bulan sebelum akhirnya tiba di padang gurun Sinai (Keluaran 19:1). Di kaki gunung itu, mereka berkemah sementara Musa naik untuk mendaki gunung itu. Di sana Allah berbicara kepada Musa bahwa orang Israel akan menjadi milik Allah sendiri di antara semua bangsa, dengan syarat mereka sungguh-sungguh mendengarkan firman Tuhan dan berpegang pada perjanjianNya (Keluaran 19:5). Perintah-perintah dan peristiwaperistiwa setelah itu mengisyaratkan bahwa sesuatu yang dahsyat akan segera terjadi. Pada masa pengudusan selama tiga hari, orang Israel harus mencuci pakaian dan mempersiapkan diri (Keluaran 9-15). Setelah itu, mereka menghampiri kaki gunung dan segera Allah menyatakan diriNya dalam kebesaran dan keagungan (WS Lasor dkk 1995:204/5).

Dalam Keluaran 19:16-18 dikatakan : 'Dan terjadilah pada hari ketiga, pada waktu terbit fajar, ada guruh dan kilat dan awan padat di atas gunung dan bunyi sangkakala yang sangat keras, sehingga gemetarlah seluruh bangsa yang ada di perkemahan (ayat 16). Lalu Musa membawa bangsa itu keluar dari perkemahan untuk menjumpai Allah dan berdirilah mereka pada kaki gunung (ayat 17). Gunung Sinai ditutupi seluruhnya dengan asap, karena TUHAN turun ke atasnya dalam api; asapnya membubung seperti asap dari dapur, dan seluruh gunung itu gemetar sangat (ayat 18). Di tengah suasana yang mendebarkan ini, Allah kemudian memanggil Musa dan memberikan sepuluh perintah sebagaimana yang terdapat dalam Keluaran 20:2-17.

Harus diakui bahwa sepuluh perintah ini memiliki status yang unik dalam Alkitab dan komunitas-komunitas yang menerimanya sebagai kitab suci. Di samping itu, seri undang-undang ini juga merupakan bagian yang paling dikenal dan paling mengemuka dari pentateukh. Ia juga merupakan satu-satunya hukum

37 | Memahami dan Memaknai berbagai Peraturan, Ketetapan, dan Hukum dalam Taurat..., Sitopu, Elisamark

Jurnal Christian Humanioran | http://e-journal.iakntarutung.ac.id/index.php/humaniora 
yang diberikan secara langsung oleh Allah kepada umatNya. Ditulis dalam lohloh batu dan ditempatkan dalam tabut perjanjian (Dale Patrick 1986:35)

Dalam konteksnya, sepuluh perintah juga sangat istimewa. Keistimewaannya terletak pada kata-kata yang disampaikan oleh Allah pada umatNya yang berbeda dari ketetapan-ketetapan, peraturan-peraturan serta ketentuan-ketentuan dari bangsa lain. Umumnya, ketetapan-ketetapan atau peraturan-peraturan dari bangsa lain, menangani persoalan secara satu per satu atau kasus per kasus. Namun dalam sepuluh perintah ini, bentuknya berupa ucapan langsung dari Allah kepada umat. Bentuk seperti ini, dapat dibandingkan dengan bentuk dokumen perjanjian raja Hitit dari abad ke 14 dan 13 SM (Wismoady Wahono 2002:112).

Dokumen perjanjian para raja Hitit, merupakan dokumen perjanjian antara raja Hitit dengan raja-raja yang ditaklukkannya. Atau dengan bahasa lain, dokumen ini merupakan dokumen antara raja taklukan dengan raja yang menaklukkan. Dokumen ini dimulai dengan satu prolog dimana raja penguasa menerangkan dirinya sendiri dan mendaftar karya-karyanya yang positif terhadap pihak lain. Kemudian menyusul kewajiban-kewajiban yang harus dilakukan oleh pihak lain, meliputi larangan untuk berhubungan dengan para musuh raja serta keharusan untuk memenuhi semua tugas sebagai bawahan raja. Kesamaannya dengan sepuluh perintah ditemukan dalam prolog, menerangkan Allah : 'Akulah TUHAN, Allahmu'; lalu menyatakan karya-karya positif Allah terhadap umat 'yang membawa engkau keluar dari Mesir, dari perbudakan'. Baru kemudian menyusul kewajiban-kewajiban yang harus dipenuhi umat, diantaranya kesetiaan tunggal kepada Yahweh, kemudian menyusul suatu daftar petunjuk perilaku kehidupan yang patut dilakukan oleh umat Allah. (Wismoady Wahono 2002:112)

Sepuluh perintah dalam Keluaran 20, merupakan implementasi dari hubungan Allah dan Israel yang diikat dalam perjanjian Sinai. Allah menetapkan kewajiban-kewajiban tertentu yang harus dipatuhi oleh umat. Baik itu kewajiban terhadap Allah sendiri maupun kewajiban mereka terhadap yang lain. Ketaatan mereka akan perjanjian itu akan menjadikan mereka menjadi umat Allah (I. Suharyo 1995:40/41). Status Allah dalam sepuluh perintah sangat ditekankan dan dilindungi. Allah ditempatkan pada tempat atau urutan pertama 'first table' sementara individu, harta, keadilan dan hal-hal yang pantas mereka lakukan ditempatkan pada bagian kedua 'second table'(Dale Patrick 1986:254)

Di samping itu, sepuluh perintah merupakan landasan atau dasar yang menjadi sumber bagi banyak hukum dalam PL. Keadaan baru menuntut agar kumpulan pendek yang paling awal ini, dikembangkan dan disesuaikan. Disinilah dapat dideteksi keterkaitan antara hukum Israel dengan hukum bangsa-bangsa lain disekitarnya. Namun harus dipahami bahwa bahan-bahan asing itu, tidak diambil begitu saja. Melainkan diolah secara baru dalam pandangan keyakinan iman Israel 
akan Allah yang satu, yang telah memilih umat Israel menjadi milikNya (Band. I.Suharyo 1995:41).

\section{Kitab Perjanjian}

Bagian ini, merupakan perkembangan paling awal yang dapat ditemukan dalam kitab Keluaran. Persisnya pada bagian setelah sepuluh perintah, yakni dalam Keluaran 20:22-23:33. Bila dalam sepuluh perintah hanya ada gambaran hukum yang bersifat umum dan lebih mengarah kepada hal-hal mendasar 'legal policy' maka dalam bagian ini diperoleh gambaran yang lebih spesifik yang merupakan penjabaran dan implementasinya. Hukum yang tadinya masih dalam bentuk sederhana tanpa konsekwensi, mulai mengarah pada hukum dalam pengertian normal yang disertai dengan konsekwensi tertentu bagi yang melanggar (Band. W.S. Lasor 1992:146)

Kitab hukum ini dipahami terjadi ketika mereka memasuki tanah Kanaan sebelum periode kerajaan. Itu artinya, ada pertemuan ataupun kombinasi dengan institusi legal dengan penduduk asli Kanaan (Band. Claus Westermann 1976:64). Von Rad mengatakan, ketika suku-suku pengembara memasuki tanah Kanaan, mereka mengambil-alih sebagian besar tradisi-tradisi hukum yang sudah ada di kota-kota Kanaan. Tetapi mereka tidak mengambil alih semuanya begitu saja, ada proses seleksi atau penyelarasan yang disesuaikan dengan kebutuhan dan iman percaya mereka (Gerhard von Rad 1973:38/40).

Untuk menjelaskan isi dari kitab perjanjian ini, berikut penulis memaparkan beberapa uraian ahli. Baker mengatakan bahwa kitab perjanjian ini merupakan suatu koleksi atau kumpulan hukum yang memuat peraturan berkaitan dengan moral, sipil, dan keagamaan yang menjadi pedoman dan penuntun hidup mereka sebagai umat Allah setelah keluar dari Mesir (David L. Baker 2005:35).

Hendriks mengatakan kitab perjanjian merupakan suatu koleksi hukumhukum yang memuat peraturan yang melindungi para budak dari tindakan sewenang-wenang majikan mereka, juga perlindungan terhadap fakir miskin dalam memenuhi kebutuhan-kebutuhan pokok. Hal ini misalnya dapat dilihat dari larangan peminjaman uang dengan bunga tinggi (Keluaran 22:25) dan larangan penyuapan terhadap hakim. Di samping itu ada keharusan bagi para tuan tanah, dimana setiap tujuh tahun para tuan tanah harus membagi-bagikan hasil yang mereka peroleh demi keuntungan semua orang (Herman Hendriks 1990:35)

Wahono mengemukakan tiga hal yang berhubungan dengan isi kitab perjanjian (Wismoady Wahono 2002:122-124). Pertama, peraturan-peraturan yang berkaitan dengan kehidupan pertanian. Baik itu ternak, gandum, ladang, kebun anggur, dan orang-orang yang hidup secara menetap dengan bangunanbangunan tempat tinggal yang tetap.

Kedua, ditemukannya dua bentuk hukum, yaitu bentuk apodiktis dan bentuk kasuistis. Bentuk apodiktis biasanya terdapat dalam hukum atau peraturan

39 | Memahami dan Memaknai berbagai Peraturan, Ketetapan, dan Hukum dalam Taurat..., Sitopu, Elisamark Jurnal Christian Humanioran | http://e-journal.iakntarutung.ac.id/index.php/humaniora 
yang melarang, menyuruh, atau mengharuskan orang Israel untuk berbuat sesuatu. Sementara bentuk kasuistis terdapat dalam hukum-hukum atau peraturanperaturan yang menangani kasus-kasus peristiwa. Menangani secara kasus per kasus. Ada ciri khasnya, yaitu mengemukakan kasus tertentu lalu menarik kesimpulan yang mengandung prinsip umum, dengan rumusan 'apabila seseorang melakukan itu, maka ia.....' dan bentuk peraturan keagamaan berkaitan dengan dunia pertanian yang telah diperbaharui dengan makna baru seperti upacara persembahan buah-buah sulung (Keluaran 23:19) dan juga penyerahan anak-anak sulung (Keluaran 22:29-30).

Ketiga, berkaitan dengan kehidupan agamaniah dari masing-masing suku yang pada awalnya berpusat pada satu atau beberapa tempat suci. Ada tempat suci yang merupakan milik satu suku. Ada tempat suci yang merupakan milik beberapa suku. Ada imam pada masing-masing tempat suci. Dari tempat-tempat seperti itulah dikemudian hari muncul peraturan-peraturan keagamaan dari sukusuku itu. Kebanyakan tempat-tempat suci telah ada sebelum suku Israel datang. Suku Israel pendatang ini dikemudian hari mengambil alih tempat-tempat suci tersebut. Berkaitan dengan ibadah-ibadah suku-suku Israel yang berpusat pada tiga perayaan besar, yaitu perayaan 'roti tak beragi, perayaan panen, perayaan pengumpulan hasil panen (Keluaran 23:14-17) yang disebut perayaan ziarah. Semuanya dihubungkan dengan saat-saat penting pertanian. Dari uraian ini dapat dipahami bahwa ada kedekatan antara kehidupan agamaniah Israel dengan kehidupan agamaniah Kanaan.

\section{Hukum Deutronomi}

Ulangan 12-26 yang dipahami sebagai hukum deutronomi, merupakan bagian dari perkataan-perkataan Musa di dataran Moab ketika orang Israel berada di perbatasan tanah perjanjian, Kanaan (Desmont T. Alexander 2003:503). Menurut Westermann (Band. Claus Westermann 1976:81), ada bagian yang lebih luas ketika kita memperhatikan bagian awal dan akhir dari hukum deutronomi. Westermann membagi hukum deuteronomi ke dalam empat bagian. Pertama, hukum sentralisasi yang merujuk kepada tempat dimana Allah telah tentukan (Ulangan 12:1-28). Kedua, berkenaan dengan penyembahan allah-allah lain (Ulangan 12:29-13:18). Ketiga, perintah untuk membawa buah-buah pertama sebagai buah kepercayaan atau keyakinan mereka kepada Tuhan (Ulangan 26:111). Keempat, perintah untuk memberi persepuluhan dan doa (Ulangan 26:12-15).

Sentralisasi ibadah merupakan hal yang sangat penting dari semangat deutronomi. Arahan untuk memberikan persembahan dan melakukan ibadah pada satu tempat yang Allah tentukan. Dalam Ulangan 12:2-7 secara tajam dibedakan cara pemujaan umat dengan pemujaan orang Kanaan yang melakukan penyembahan di banyak tempat, juga dengan berbagai macam simbol dan bentuk yang termanifestasi misalnya dalam Baal. Tetapi umat hanyalah menyembah Yahweh yang tunggal, yang tidak tercampur dengan yang lain (Ulangan 12:8-12). 
Deutronomi menempatkan Israel sebagai suatu komunitas sakral, umat yang kudus, dan umat kepunyaanNya (Gerhard von Rad 1962:226-227)

Inti dari deutronomi adalah pengajaran yang mengusahakan umat Israel mendengar penyataan Tuhan dan setia kepadaNya dalam segala keadaan. Kepatuhan yang dimaksud Tuhan dalam deutronomi bukan dalam pengertian sebagai prasyarat pemilihan saja, akan tetapi lebih dari pada itu. Hal ini secara jelas diekspresikan dalam Ulangan 27:9-10 '....Diamlah dan dengarlah, hai orang Israel. Pada hari ini engkau telah menjadi umat TUHAN, Allahmu (ayat 9). Sebab itu engkau harus mendengarkan suara TUHAN, Allahmu, dan melakukan perintah dan ketetapanNya, yang kusampaikan kepadamu pada hari ini (ayat 10).' Oleh karenanya, sebagai umat Allah mereka diminta untuk secara penuh setia pada perintah-perintahNya sebagai bukti kecintaan pada Tuhan dan juga ucapan syukur atas berkat dan keselamatan yang telah Tuhan limpahkan. (Gerhard von $\operatorname{Rad} 1962: 226-227)$.

Hukum deutronomi mulai berlaku pada masa pemerintahan raja Yosia (640-609 SM). Hukum ini menyangkut suatu masyarakat yang menetap dan terpusat. Didalamnya ditemukan perbedaan ekonomi dan sosial yang tingkat kesenjangannya tinggi. Untuk itu boleh dikatakan kalau hukum ini merupakan suatu kemajuan dari hukum yang sudah ada sebelumnya. Jikalau undang-undang perjanjian praktis hanya terbatas pada area kota, maka undang-undang deutronomi ini, berlaku untuk seluruh Israel.

\section{Hukum Kekudusan}

Nama hukum kekudusan berasal dari teguran atau peringatan dalam pengantar Imamat pasal 19, lebih tepatnya ayat 2 dengan mengatakan 'Kuduslah kamu, sebab Aku, TUHAN, Allahmu, kudus.' Kalimat ini mengalami pengulangan beberapa kali dalam Imamat 20:7, 26; 21:6; cf. 22:31-33, (WS Lasor dkk 1992:69).

Bagian hukum kekudusan (Imamat 17-26) sesuai dengan namanya, sangat menekankan kekudusan. Karakter dan sifat umat Israel haruslah juga kudus sebagaimana karakter dan sifat Tuhan sendiri. Tuhan adalah standar kekudusan yang mana segala sesuatu harus mengacu kepada standar itu. Pada saat yang sama, Tuhan juga menjadi motif dan motivator bagi manusia untuk dapat hidup kudus. Secara fundamental, Allah adalah kudus. Ia unik dan tak dapat dibandingkan. Oleh karenanya, umat juga harus menunjukkan diri sebagai yang unik dan umat yang dipanggil dan dipilih oleh Tuhan. dalam prinsip-prinsip etis dan kehidupan praktis, mereka wajib menunjukkan hidup yang berkenan kepadaNya. Menunjukkan kehidupan yang mencerminkan gambar Allah image of God (Roy B. Zuck 1991:58)

Berkaitan dengan panggilan untuk hidup kudus, di dalam hukum kekudusan ada aturan-aturan, yaitu mengenai pengudusan darah (Imamat 17),

41 | Memahami dan Memaknai berbagai Peraturan, Ketetapan, dan Hukum dalam Taurat..., Sitopu, Elisamark Jurnal Christian Humanioran | http://e-journal.iakntarutung.ac.id/index.php/humaniora 
larangan terhadap hubungan seks terhadap saudara incest (Imamat 18:1-18) dan larangan-larangan atau aturan-aturan yang berhubungan dengan hal seksual (Imamat 18:19-23), memelihara sepuluh perintah (Imamat 19:19-20:17), mengenai tingkah laku yang pantas dari para imam secara khusus, dan perihal kehidupan umat dalam Imamat 21-22 (Roy B. Zuck 1991:58).

Sebagai suatu bangsa yang kudus, umat Israel juga harus memahami halhal yang berkaitan dengan kekudusan itu. Misalnya perintah hari Sabat, dimana mereka harus mengkhususkan hari itu sebagai hari untuk Tuhan, hari perhentian penuh, hari pertemuan khusus dengan Tuhan dimana tidak boleh ada yang bekerja. Perintah ini berlaku atas segala tempat kediaman orang Israel (Imamat 23:3). Di samping itu juga, merayakan paskah dan perayaan roti tak beragi (Imamat 23:4-8), pesta buah-buah pertama (Imamat 23:9-14), pesta mingguan (Imamat 23:15-22), pesta trompet (Imamat 23:23-25), hari pendamaian (Imamat 23:26-32), hari raya pondok daun (Imamat 23:33-34), tahun sabat (Imamat 25:127), dan tahun jubileum (Imamat 25:8-55). Tujuan dari perayaan-perayaan atau upacara-upacara itu adalah beragam. Namun demikian tetap berada dalam kerangka kekudusan untuk mengingatkan umat Allah, baik itu tentang orangorang tertentu, tempat-tempat tertentu, peristiwa-peristiwa tertentu yang semuanya dipahami sebagai sesuatu yang penting dan kudus. Dengan pemahaman ini, harus ada pemisahan antara hari-hari atau waktu-waktu itu dengan hari-hari biasa atau hal-hal yang sekuler. Pemisahan ini dilakukan dengan penentuan kalender (Roy B. Zuck 1991:58).

\section{KESIMPULAN DAN SARAN}

Berbagai macam peraturan, ketetapan, dan hukum, bukanlah merupakan sesuatu yang terjadi begitu saja. Kemunculannya berkaitan erat dengan keadaan situasional mereka. Baik itu yang bersifat sosial, budaya, ekonomi, politik, dan keagamaan. Oleh karenanya ada proses atau perkembangan. Kemunculannya bertujuan untuk menata dan menuntun umat untuk hidup benar. Di samping itu juga memberi arahan bagi umat di tengah kehidupan mereka, baik itu kehidupan keseharian mereka sendiri, juga kehidupan dengan orang-orang yang ada disekitar mereka 'the others', yang menunjukkan identitas mereka sebagai umat Allah yang terpilih.

Adanya kemiripan antara hukum-hukum versi taurat dengan hukumhukum versi lain di sekitar Israel terjadi karena mereka hidup dan berkembang di tengah bangsa-bangsa lain. Ada interaksi ataupun komunikasi yang terjadi di antara bangsa Israel dengan bangsa-bangsa lain itu. Namun demkian, sebagaimana telah dijelaskan dalam bagian sebelumnya, tetap ada seleksi atau penyaringan terhadap berbagai hukum bangsa lain itu. Hukum-hukum bangsa lain itu tidak diambil begitu saja. Hal-hal yang bertentangan dengan iman dan kepercayaan mereka akan disingkirkan atau diabaikan.

$42 \mid$ Memahami dan Memaknai berbagai Peraturan, Ketetapan, dan Hukum... Sitopu, Elisamark Jurnal Christian Humanioran | http://e-journal.iakntarutung.ac.id/index.php/humaniora 
Dalam perspektif penulis, hukum-hukum yang terdapat dalam Taurat adalah unik. Keunikan ini bisa dirasakan ketika kita masuk lebih jauh dan mendalam akan berbagai hukum ini. Keunikan ini, ada pada refleksi mereka akan keterlibatan Allah. Allah menjadi landasan dari pemberlakuan hukum-hukum yang mengatur kehidupan umat itu. Itu artinya, Allah tidak dapat dipisahkan dalam kehidupan mereka. Baik itu dalam kehidupan religius maupun kehidupan sekuler mereka

Berbagai macam peraturan, ketetapan, dan hukum yang terdapat di dalam kitab Taurat ternyata tidak seperti yang kita bayangkan sebelumnya. Kalau sebelumnya kita memahaminya secara sederhana, kaku, dan asing, ternyata setelah digali dan dipahami secara mendalam, kita menemukan banyak hal baru. Untuk itu diperlukan koreksi dan reinterpretasi terhadap paham-paham yang salah dan keliru selama ini. Melihat dan memahami berbagai ketetapan, peraturan, dan hukum itu dalam konteksnya. Dengan cara ini, nilai utama yang menjadi tujuan pemberlakuan berbagai aturan dan hukum itu dapat tergali sehingga mampu menjadi penuntun yang sejati bagi kita umat Allah.

\section{DAFTAR PUSTAKA}

Alexander, Desmond T., Baker, David W. (peny.). 2003. Law dalam Dictionary of the Old Testament: Pentateuch. England, Leicester: Inter Varsity Press.

Baker, David L. 2005. Mari Mengenal Perjanjian Lama. Jakarta: BPK Gunung Mulia.

Barth, Ch. 1970. Theologia Perjanjian Lama I. Jakarta: BPK Gunung Mulia.

Freedman, David Noel (peny.). 1992. Torah dalam the Anchor Bible Dictionary:

Volume K-N, New York, London, Toronto, Sydney, Auckland: Doubleday.

Hendriks, H. 1990. Keadilan Sosial dalam Kitab Suci. Yogyakarta: Kanisius.

Hill, Andrew E., Walton, John H. 1996. Survey Perjanjian Lama. Malang: YP Gandum Mas.

Lasor, W.S., Hubbard, D.A., Bush, F. W. 1995. Pengantar Perjanjian Lama I: Taurat dan Sejarah. Jakarta: BPK Gunung Mulia. . 1992. Old Testament Survey: the Message, Form, and Background of the Old Testament. Michigan, Grand Rapids: William B. Eerdmans Publishing Company.

Patrick, D. 1986. Old Testament Law. London: SCM Press.

Suharyo, I. 1995. Membaca Kitab Suci: Mengenal Tulisan-tulisan Perjanjian Lama. Yogyakarta: Penerbit Kanisius.

Von Rad, G. 1973. Musa. Jakarta : BPK Gunung Mulia. .1962. Old Testament Theology: the Theology of Israel's Historical Tradition. Edinburgh \& London: Oliver \& Boyd.

43 | Memahami dan Memaknai berbagai Peraturan, Ketetapan, dan Hukum dalam Taurat..., Sitopu, Elisamark Jurnal Christian Humanioran | http://e-journal.iakntarutung.ac.id/index.php/humaniora 
Wahono, W. 2002. Di sini Kutemukan. Jakarta: BPK Gunung Mulia.

Westermann, C. 1976. Handbook to the Old Testament. Minneapolis, Minnesota: Augsburg Publishing House.

Zuck, Roy B. (peny.). 1991. A Biblical Theology of the Old Testament. Chicago: Moody Press. 